\title{
Prevalence of Malaria and Typhoid Fever Co-infection among Febrile Patients Attending College of Health Technology Medical Centre in Calabar, Cross River State, Nigeria
}

\author{
Orok, Daniel Archibong ${ }^{1}$,Usang, Akedor Ibor ${ }^{1}$,Ikpan, Ogbe Oyama ${ }^{1}$,Duke, Edisua E ${ }^{1}$, \\ Eyo, Emem Efeffiom ${ }^{1}$, Edadi Ukam Ekup ${ }^{1}$, Ati $^{2}$, Boniface Unimke and Udida, Job Akung \\ ${ }^{1}$ Department of Medical Laboratory Science, College of Health Technology, Calabar, Nigeria \\ ${ }^{2}$ Department of Biochemistry, Faculty of Basic Medical Sciences, University of Calabar, \\ Calabar, Nigeria \\ *Corresponding author
}

\begin{abstract}
A B S T R A C T
Keywords

Typhoid fever,

Co-infection,

Febrile

patients,

Calabar

\section{Article Info}

Accepted:

24 March 2016

Available Online:

10 April 2016

A study on prevalence of malaria and typhoid fever co-infection among febrile patients was carried out in College of Health Technology Medical Centre, Calabar, Cross River State, between January and December, 2015. Venepunture technique was used for collection of the blood samples. A total of 250 patients with clinical suspicion of malaria and typhoid fever comprising of 113 males and 137 females were examined. Giemsa stained thick and thin blood films were used to detect malaria parasites in the samples. Typhoid fever was diagnosed from each sample using Widal reagents and cultural method. Out of the 250 patients, 202 (80.8\%) tested positive for malaria, $117(46.8 \%)$ tested positive for typhoid by the Widal test and $2(0.8 \%)$ with blood culture. Males 97 (85.8\%) were more infected with malaria than females $105(76.6 \%)$ but there was no statistically significant difference $(\mathrm{P}>0.05)$ in the prevalence of infection while the prevalence of typhoid fever was higher in females 77 (56.2\%) than males 40 (35.4\%) and was statistically significant $(\mathrm{P}<0.05) .70(28.0 \%)$ were co-infected with malaria and typhoid, out of these, $24(21.2 \%)$ were co-infected with malaria and typhoid among the males and $46(33.8 \%)$ were co-infected with malaria and typhoid among the females. Coinfection was highest in the age group of $1-15$ years in both males and females. The rate of co-infection was high when typhoid fever was diagnosed by Widal (28.0\%) than by blood culture method $(0.8 \%)$. Thus, incidence of typhoid and malaria co-infection will greatly reduce if the diagnosis of typhoid fever in malaria endemic areas such as Calabar is based on blood culture.
\end{abstract}

\section{Introduction}

The term Malaria originates from medieval Italian; mal and aria meaning "bad air". The disease was formally called "ague" or "marsh fever" due to its association with swamps and marsh land (Reither, 1999). The term first appeared in the English Literature about 1829 (Strong, Richard P, 1944). 
Malaria is one of the febrile illness and the most common fatal disease in the world caused by one or more species of plasmodium. These are plasmodium falciparum, P. Vivax, P. Ovale, P. Malariae, and P. Knowlesi. Most deaths are caused by $P$. falciparum because others generally cause a milder form of malaria (WHO, 2011). The disease is transmitted by the biting of female anopheles mosquitoes, and the symptoms usually begins ten to fifteen days after being bitten (Malaria Fact Sheet, 2014). Malaria causes symptoms that typically include fever, fatique, vomiting, and headaches. In severe cases it can cause yellow skin, seizures, coma, or death (Caraballo, 2014).

Globally, an estimated half of the world population (3.4 billion people) lives in area at risk of malaria infections. Six countries in Sub-Sahara Africa (Nigeria, Democratic Republic of the Congo, Tanzania, Uganda, Mozambique and Cote d'ivore) account for an estimated 103 million malaria cases and $47 \%$ of the global total each year. Nigeria and the Democratic Republic of the Congo together account for $40 \%$ of the estimated total global (Global Malaria Action, 2013).

Malaria is holoendemic in Nigeria (Ukpai and Ajoku, 2001).Ninety percent (90\%) of Nigeria's population are at risk of malaria and it contributes also to an estimated $11 \%$ maternal mortality (WHO, 2013). There are an estimated 100 million malaria cases with over 300,000 deaths per year in Nigeria, about 100,000 more than the death from HIV/AIDS (WHO, 2013). It accounts for $60 \%$ of outpatient visits, $30 \%$ hospitalization's among children less than 5 years of age and $11 \%$ maternal mortality (Rupashree et al., 2014).

Typhoid fever also known as typhoid is a symptomic bacterial infection. Typhoid fever is caused by species of Salmonella.
The species and strains of Salmonella that commonly cause typhoid fever in humans are Salmonella paratyphi A, Salmonella paratyphi B, Salmonella paratyphi $C$ and Salmonella typhi (Lerner and Lerner, 2003). It is largely a disease of developing nations due to their poor sanitation and poor hygiene (Wain et al., 2015). It is spread by eating food or drinking water contaminated with faeces of an infected person (WHO, 2008). Transmission by flies such as Musca domestica has also been reported (Centre for Disease Control and Prevention, 2007). The most prominent feature of the infection is fever (Nnabuchi and Babalola, 2008). Globally, typhoid fever is an important cause of morbidity in many region of the world with an estimated $12-33$ million cases leading to 216,000 - 600,000 deaths annually (Pang et al., 1995).

An association between malaria and typhoid fever (malaria - typhoid co-infection) was first described in the Medical Literature in the middle of the $19^{\text {th }}$ century and was named typhoid-malarial fever by the United State Army Doctor Joseph J. Woodward $(1833$ - 1884) in 1862 . Typhoid - malaria fever was found among young soldiers during the American Civil War who were suffering from febrile illness that seemed to be typhoid rather than a new species of disease (Bynun, 2002).

Like malaria, there is a popular belief that typhoid fever is endemic and quite prevalent in Nigeria (Ohanu et al., 2003). Patients, who fail to respond to the first line of malaria treatment usually, suspect typhoid fever (Onuigbo, 1990). Malaria and typhoid usually present similar symptoms particularly at the beginning of typhoid fever (Nsutebu et al., 2001). Owing to the fact that it is sometimes very difficult to differentiate clinically the presentation of typhoid fever from that of malaria without laboratory 
support (Rooth and Bjorkman, 1992). Many clinicians usually request that both tests be performed on individuals presenting with fever of malarial typhoid signs and symptoms co-infection with malaria and typhoid is believed to be common and therefore the simultaneous treatment of both infection is quite rampant ( $\mathrm{Mbu}$ et al., 2003).

Malaria and typhoid fever remain the disease of major public health importance and cause of morbidity and mortality in tropical Africa. Both diseases are common in many countries of the world where the prevailing environmental conditions of warm, humid climate, poor sanitary habits, poverty and ignorant exist. These two diseases have been associated with poverty and underdevelopment (Ammon, 2013).

The main objectives of this study, to investigate the rate of co-infection with respect to the use of widal test and blood culture methods for diagnosing typhoid fever in College of Health Technology Medical Centre, Calabar. To determine the prevalence of malaria and typhoid fever among febrile patients in College of Health Technology Medical Centre, Calabar. To investigate the relationship between malaria and typhoid fever infections among patients presenting with fever in a twelve (12) month period at College of Health Technology Medical Centre, Calabar.

\section{Materials and Methods}

\section{Study Area}

The study was conducted from January 2015 to December, 2015 at College of Health Technology Medical Center, Mary Slessor Avenue, Calabar, Cross River State. The College Medical Centre located in Calabar, the capital of Cross River State, Nigeria is meant to render services to students and staffs in the College and the general public. Calabar also referred to as "Canaan City" (Falola and Amanda, 2007) is adjacent to the Calabar and Great Kwa Rivers and Creeks of the Cross River (from its inland delta).

Administratively, the city is divided into Calabar Municipal and Calabar South Local Government Areas. It has an area of 406 square kilometers and a total population of 371,022 at the 2006 population census (Simon, 2010). Calabar has a tropical monsoon climate with a lengthy wet season spanning ten months and a short dry season covering the remaining two months. It has average temperature ranging from 25 to 28 degree Celsius and an annual rainfall average of 3,000 millimetres (Hackett, 1989).

\section{Subjects Selection}

A total number of two hundred and fifty (250) febrile patients (age ranged 1 to 75 years) consisting of one hundred and thirteen (113) males and one hundred and thirty seven (137) females suspected for malaria and/or typhoid fever who had not taken antimalarial drugs and/or antibiotics within two weeks were included. Patients with underlying disease were excluded from the study

\section{Ethical Consideration}

Approval was obtained from College of Health Technology Medical Centre. Written informed consent was obtained from each study subject or guardian of the wards and confidentiality of the participant's results ensured throughout the research.

\section{Sample Collection and Processing}

Five millilitres of blood drawn by venepuncture from each patient were tested for malaria parasites, Salmonella typhi O 
and $\mathrm{H}$ antibodies and also cultured for $S$. typhi. The collected blood samples were analyzed within 30 minutes of collection.

\section{Parasitological Examination}

Giemsa - stained thick and thin blood films were prepared for each sample according to standard method. The films were examined microscopically by a qualified and licensed Medical Laboratory Scientist for the presence of malaria parasites within red blood cells in thin films. For thick film, the trophozoites and gametocytes were looked for. A smear was considered negative for malaria parasites if no parasites were seen after examining at least 100 microscopic fields (Monica, 2005).

\section{Widal Test}

The widal agglutination test was performed on all blood samples by the rapid slide titration method using Cromatest Widal commercial antigen suspensions, (Linear Chemicals \& L Barcelona, Spain) for the somatic (O) and flagella $(\mathrm{H})$ antigens according to manufacturer's instructions. A positive widal test was considered for any serum sample with antibody titre $\geq 1: 160$ to the $\mathrm{O}$ antigen of $S$. typhi.

\section{Bacteriological Blood Culture}

Two millilitres of each blood sample were aseptically introduced into $18 \mathrm{ml}$ of thioglycolate broth and incubated at $37^{\circ} \mathrm{C}$ for an initial period of 48 hours and subcultured on macConkey agar. S. typhi organisms were indentified on the basis of standard cultural, microscopic and biochemical characterization (Cowan, 1981). Inoculated blood culture media was discarded as negative if there was no growth after 7 to 10 days.

\section{Identification}

Positive samples were identified on the basis of microscope for malaria parasite and agglutination reaction for widal test by a trained Medical Laboratory Scientist at College of Health Technology Diagnostic Laboratory. The following plus sign scheme was used to report parasite numbers as follows:

1 - 10 parasites per 100 high power fields -$-+$

11 - 100 parasites per 100 high power fields $---++$

$1-10$ parasites in every high power field --$+++$

More than 10 parasites in every high power field --- ++++

(Monica, 2005)

The degree of agglutination was recorded in titres according to manufacturer's instruction of Cromatest antigen suspension reagents as follows:

No agglutination

$$
<1: 20
$$

Scanty agglutination $\quad 1: 40$

Slight agglutination $\quad 1: 80$

Heavy agglutination $\quad 1: 160$

Very heavy agglutination $\quad 1: 320$

\section{Data Analysis}

The data generated from this study were presented using descriptive statistics. The results were analyzed in percentage and Chisquare. 


\section{Results and Discussion}

A total of two hundred and fifty (250) febrile patients were examined for malaria using Giemsa stain and typhoid fever using Cromatest Widal reagent. Out of the numbers, *202 $(80.8 \%)$ had malaria parasite and 117 (46.8\%) had typhoid fever (Table 3.1).

The prevalence of malaria and typhoid between genders is shown in Table 3.2. Out of the 250 febrile patients examined, 97 $(85.8 \%)$ of the males and $105(76.6 \%)$ of the females were positive of malaria while $40(35.4 \%)$ of the males and $77(56.2 \%)$ of the females were positive of typhoid fever. There was no significant difference $(\mathrm{P}>0.05)$ between the male and female febrile patients infected with malaria while there was a significant difference $(\mathrm{P}<0.05)$ between the male and female febrile patients infected with typhoid fever.

Calculated $\mathrm{X}^{2}$ value for malaria $=0.317$

Critical $X^{2}$ value $=3.841$

df $=1$

$\mathrm{P}>0.05$

Since the calculated $X^{2}$ value for malaria is less than the critical $X^{2}$ value at $P>0.05$, there is no significant difference between the male and female patients infected with malaria.

Calculated $\mathrm{X}^{2}$ value for typhoid $=11.701$

Critical $\mathrm{X}^{2}$ value $=3.841$

df $=1$

$\mathrm{P}<0.05$

Since the calculated $X^{2}$ value for typhoid is greater than the critical $X^{2}$ value at $P<0.05$, there is a significant difference between the male and female patients infected with typhoid fever.
The age incidence of malaria and typhoid fever among febrile patients is shown in (Table 3.3). The participants were aged between 1 and 75 years. More participants were in the age group of 31 - 45 years and the least were in the age group of $61-75$ years. Among the age groups, $1-15$ years had the highest malaria prevalence rate of $15(93.8 \%)$ while $61-75$ years had the least malaria prevalence rate of $5(55.6 \%) .31-$ 45 years had the highest typhoid prevalence rate of $48(54.5 \%)$ while $46-60$ years had the least typhoid prevalence rate of $22(40.7 \%)$.

Out of the 250 febrile patients examined for co-infection (Table 3.4), 70(28.0\%) were coinfected with malaria and typhoid fever. Among these numbers, 24(21.2\%) of the males were co-infected while $46(33.6 \%)$ of the females were co-infected.

The age incidence of co-infection with malaria and typhoid fever is shown in Table 3.5. The age group of $1-15$ years of the males had the highest co-infection $3(37.5 \%)$, and the age of $61-75$ years of the males had no co-infection $0(0 \%)$ while the age group of $1-15$ years of the females had the highest co-infection of $3(37.5 \%)$ and the age group of $61-75$ years of the females had the least co-infection 1(14.3\%).

Out of the 250 febrile patients examined (Table 3.6), 2(0.8\%) were co-infected with malaria parasite and typhoid fever using Giemsa stain and blood culture.

The study shows that the overall prevalence of malaria 202(80.8\%) and typhoid fever $117(46.8 \%)$ were quite high. The prevalence of malaria obtained in this study was similar to figure in Sierra Leone who reported prevalence of $79.94 \%$ while the prevalence of typhoid fever was lower than the prevalence rate of $83.54 \%$ obtained in the 
same area (Michaella et al., 2014). The overall prevalence rates were however higher than the $38.78 \%$ and $42.86 \%$ reported by Okore et al for residents of Obuda - Aba, Abia State, $36.5 \%$ and $19 \%$ by Meseret et al at rural health centre in Northwest Ethiopia and $8 \%$ and $38.5 \%$ by V.A Pam et al at antenatal clinics in Wuse Central Hospital, Abuja. The high prevalence rates obtained in this study could probably be due to the fact that the area is endemic with high and perennial transmission especially in the raining season, poor access to clean water, poor access or adherence to effectives control measures such as the use of insecticide treated nets (ITNs).

The prevalence of malaria was higher in males $97(85.8 \%)$ than females $105(76.6 \%)$, but there was no statistically significant association $(\mathrm{P}>0.05)$. On the contrary another study done by A. J. Sundufu et al in Sierra Leone showed that females $(53.4 \%)$ are more affected than males $(46.6 \%)$. This might be due to the fact that males often refuse to sleep inside insecticide treated nets, sleeping late in the night and have greater chance to travel to malaria endemic area for daily labour to make both ends meet. The prevalence of typhoid fever was greater in females $77(56.2 \%)$ than males 40(35.4\%), and was statistically significant $(\mathrm{P}<0.05)$. However, other previous studies in Sokoto, showed that the frequency of typhoid fever was greater in males, $29.4 \%$ than in females, $22.9 \%$ (H.M. Alhassan et al., 2012). This suggests that females may be more prone to the disease. Females may acquire infection from unhygienic environment, during child care, improper food preparation and other household activities, thus increasing the frequency of typhoid fever.

Among the age groups, those within the age group of 1-15 years had the highest prevalence of malaria $15(93.8 \%)$ while those in $61-75$ years had the least $5(55.6 \%)$. This is consistent with the general observation that the age group is more vulnerable to the disease in areas of high transmission (H.M. Gilles, 1993). Naturally acquired immunity builds up in older adults following repeated exposure to the parasite and is manifested by lower parasite densities and fewer clinical malarial episodes than younger children (S.K. Sharma et al, 2004). Those within the age group of $31-45$ years had the highest prevalence rate of typhoid fever $48(54.5 \%)$ while $46-60$ years had the least 22(40.7\%). This is contrast with the report of Okore et $a l$., which showed that age group of $46-60$ years had the highest prevalence rate of typhoid fever, $48.33 \%$. The higher prevalence among the age group of $31-45$ years could be as a result of the individuals patronizing restaurants where they buy food from food vendors which may not be well prepared in a clean environment and drinking any available water.

The co-infection of malaria and typhoid fever using widal reagents is $70(28.0 \%)$, among who were 24(21.2\%) males and $46(33.8 \%)$ females. On the contrary, a coinfection prevalence rate of $10(5.0 \%)$, $2(20.0 \%)$ males and $8(80.0 \%)$ females were reported in Ekwulumili. The higher coinfection rate amongst females occur due to the fact that most female farmers and traders spend their time in the farms and markets where they may have no other sources of drinking water and hence to drink water from streams and sachet water and are also easily expose to mosquitoes bite (Agwu et al., 2008). On the age group, 1- 15 years had the highest co-infection rate $3(37.5 \%)$ in both males and females and $61-75$ years had the least $1(14.3 \%)$ in females. This agrees with the work of Onyido et al., who had the age group of $1-10$ years as the highest co-infection rate, $1(11 \%)$ and $51-$ 60 years as the least, $1(2.78 \%)$. 
Table.3.1 Overall Prevalence of Malaria using Giemsa Stain and Typhoid Fever using Widal Reagent among Febrile Patients

\begin{tabular}{lccc}
\hline Illness & No. examined & No. infected & Percentage (\%) \\
\hline Malaria & 250 & 202 & 80.8 \\
Typhoid & 250 & 117 & 46.8 \\
\hline
\end{tabular}

Table.3.2 Frequency and Distribution of Malaria using Giemsa Stain and Typhoid Fever using Widal Reagents between Genders of Febrile Patients

\begin{tabular}{|c|c|c|c|c|c|c|c|}
\hline Sex & $\begin{array}{l}\text { No. } \\
\text { tested }\end{array}$ & $\begin{array}{l}\text { No. } \\
\text { infected } \\
\text { with } \\
\text { malaria } \\
\text { (observed } \\
\text { freq.) }\end{array}$ & $\begin{array}{l}\text { Expected } \\
\text { Freq. }\end{array}$ & $\begin{array}{l}\text { Percentage } \\
\text { positive } \\
(\%)\end{array}$ & $\begin{array}{l}\text { No. } \\
\text { infected } \\
\text { with } \\
\text { typhoid } \\
\text { (observed } \\
\text { freq.) }\end{array}$ & $\begin{array}{l}\text { Expected } \\
\text { Freq. }\end{array}$ & $\begin{array}{l}\text { Percentage } \\
\text { positive } \\
(\%)\end{array}$ \\
\hline $\mathrm{M}$ & 113 & 97 & 101 & 85.8 & 40 & 58.5 & 35.4 \\
\hline $\mathrm{F}$ & 137 & 105 & 101 & 76.6 & 77 & 58.5 & 56.2 \\
\hline Total & 250 & 202 & 202 & 80.8 & 117 & 117 & 46.8 \\
\hline \multicolumn{8}{|l|}{ Key: } \\
\hline M & - & Males & & & & & \\
\hline $\mathrm{F}$ & - & Females & & & & & \\
\hline Freq & - & Frequency & & & & & \\
\hline
\end{tabular}

Table.3.3 Age Incidence of Malaria Parasite using Giemsa Stain and Typhoid Fever using Cromatest Widal Reagents among Febrile Patients

\begin{tabular}{lccccc}
\hline Age group & No. Tested & $\begin{array}{c}\text { No. infected } \\
\text { with malaria }\end{array}$ & $\begin{array}{l}\text { Percentage } \\
\text { Positive (\%) }\end{array}$ & $\begin{array}{c}\text { No. infected } \\
\text { with typhoid }\end{array}$ & $\begin{array}{l}\text { Percentage } \\
\text { Positive (\%) }\end{array}$ \\
\hline $1-15$ & 16 & 15 & 93.8 & 8 & 50.0 \\
$16-30$ & 83 & 67 & 80.7 & 35 & 42.2 \\
$31-45$ & 88 & 71 & 80.7 & 48 & 54.5 \\
$46-60$ & 54 & 44 & 81.5 & 22 & 40.7 \\
$61-75$ & 9 & 5 & 55.6 & 4 & 44.4 \\
Total & $\mathbf{2 5 0}$ & $\mathbf{2 0 2}$ & $\mathbf{8 0 . 8}$ & $\mathbf{1 1 7}$ & $\mathbf{4 6 . 8}$ \\
\hline
\end{tabular}

Table.3.4 Frequency and Distribution of Co-Infection with Malaria using Giemsa Stain and Typhoid using Widal Reagent between Genders of Febrile Patients

\begin{tabular}{llcl}
\hline Sex & No. tested & $\begin{array}{c}\text { No. infected with } \\
\text { both malaria/typhoid }\end{array}$ & $\begin{array}{l}\text { Percentage } \\
\text { Positive } \mathbf{( \% )}\end{array}$ \\
\hline Male & 113 & 24 & 21.2 \\
Female & 137 & 46 & 33.8 \\
Total & 250 & 70 & 28.0 \\
\hline
\end{tabular}


Table.3.5 Age Incidence of Co-Infection with Malaria Parasite using Giemsa Stain and Typhoid Fever using Widal Reagent between Genders of Febrile Patients

\begin{tabular}{lllllll}
\hline $\begin{array}{l}\text { Age } \\
\text { group }\end{array}$ & $\begin{array}{l}\text { No. } \\
\text { tested }\end{array}$ & $\begin{array}{l}\text { No. } \\
\text { infected }\end{array}$ & $\begin{array}{l}\text { Percentage } \\
\text { Positive } \\
(\boldsymbol{\%})\end{array}$ & No. tested & $\begin{array}{l}\text { No. } \\
\text { infected }\end{array}$ & $\begin{array}{l}\text { Percentage } \\
\text { Positive } \\
(\boldsymbol{\%})\end{array}$ \\
\hline- & Male & Male & Male & Female & Female & Female \\
$1-15$ & 8 & 3 & 37.5 & 8 & 3 & 37.5 \\
$16-30$ & 34 & 5 & 14.7 & 49 & 16 & 32.7 \\
$31-45$ & 41 & 12 & 29.3 & 47 & 17 & 36.2 \\
$46-60$ & 28 & 4 & 14.3 & 27 & 9 & 33.3 \\
$61-75$ & 2 & 0 & 0 & 7 & 1 & 14.3 \\
Total & $\mathbf{1 1 3}$ & $\mathbf{2 4}$ & $\mathbf{2 1 . 2}$ & $\mathbf{1 3 7}$ & $\mathbf{4 6}$ & $\mathbf{3 3 . 6}$ \\
\hline
\end{tabular}

Table.3.6 Overall Prevalence of Co-Infection with Malaria using Giemsa Stain and Typhoid Fever using Blood Culture

\begin{tabular}{lccc}
\hline Illness & No. examined & No. infected & $\begin{array}{l}\text { Percentage } \\
\text { Positive (\%) }\end{array}$ \\
\hline $\begin{array}{l}\text { Co-infection with } \\
\text { malaria and typhoid }\end{array}$ & 250 & 2 & 0.8 \\
\hline
\end{tabular}

The result of the co-infection using blood culture was $2(0.8 \%)$. This is in agreement with the study in Kaduna, $0.5 \%$ (F.A. Mbuh et al., 2003), Sierra Leone, $0.6 \%$ (A.J. Sundufu et al., 2012) and Ebonyi, 0.8\% (A,C.Nwuzo et al., 2009) but less than the study in Lagos, $19.95 \%$ (K.O. Akinyemi et al., 2007), and Enugu 26.6\% (M.E. Ohanu et al., 2003). Even though blood culture is a gold standard test for typhoid fever diagnosis, it can be affected by duration of infection, intake of antibiotics (Monica, 2006), and laboratory setup.

Because of the high prevalence of typhoid fever and malaria in the tropics, coinfections are common (C.J. Uneke, 2008). The high rate of typhoid and malaria coinfection using widal test may be responsible for the frequent treatment of mixed infection in Calabar. However, blood culture results showed that this rate of coinfection is only $0.8 \%$. Hence, typhoid fever could cross-react with malaria using widal test reagent (P. Pradhan, 2011) and lead to over diagnosis of typhoid fever. Thus, over diagnosis of typhoid fever leads to unnecessary exposure of patients to the side effects of antibiotics.

In conclusion, the study shows that malaria prevalence rate $(80.8 \%)$ is high in Calabar. The prevalence rate of malaria and typhoid fever co-infection $(28.0 \%)$ was equally high. There was a substantial result discrepancy between widal test $(46.8 \%)$ and blood culture $(0.8 \%)$ for the diagnosis of typhoid fever. However, the incidence of typhoid and malaria co-infection could be reduced to minimal if diagnosis of typhoid fever by cultural method is emphasized in our clinical hospital laboratories. This will also improve patient management by cutting down cost of treatment and eliminate other risks associated with misuse of antibiotics. 


\section{Acknowledgment}

The authors would like to express their appreciation to the Almighty God for His grace throughout the work. The authors also thank the Medical Doctor in charge of College of Health Technology Medical Center, who is one of the co-authors and other professionals for their help throughout the work. We also want to express our gratitude to the study participants for their patience and cooperation.

\section{References}

A.C. Nwozo, R.A. Onyeagba, I.R. Iroha, O. Nwoni and A.E. Oji (2009). "Parasitological, bacteriological and cultural determination of prevalence of malaria parasite ( Plasmodium falciparum) and typhoid fever coinfection in Abakiliki, Ebonyi State, "Scientific Research and Essay's vol.4, no. pp. 966-971.

A.J. Sundufu, M.S.James, and I.K Foday, (2012). "Role of co-infection with malaria parasites and Salmonella Typhi in Bo City" Southern Sierra Leone Public Health Research. Vol.2, no. 6, pp. 204-207.

Agwu, E. Ihongbe, J. C. Okogun, G. R.A. and Inyang, N.J. (2008). High incidence of co-infection with malaria and typhoid in febrile HIV infected and AIDS patients in Ekpoma, Edo State, Nigeria. Brazillian Journal of Microbiology, 40:329-332.

Bynum, B; (2002). Typhoi- malaria. Lancet, 360:1339-1339.

C.J.Uneke (2008). "Concurrent malaria and typhoid fever in the tropics: the diagnostic challenges and public health implication", Journal of Vector Borne Disease. Vol. 45, no.2, pp. 133-142.

Caraballo H. (2014). Emergency department management of mosquito-borne illness: malaria, dengue, and west nile virus. Emergency medicine practice 16(5).

Center for Disease Control and Prevention, Malaria: Life cycle of Plasmodium species (2007). Online. Available http://www.cdcgov/malaria/plasmodiu m species.html, Accessed on 23 April, 2015.

Cowan S.T. Cowan and Steel's (1981). Manual for the identification of Medical bacteria.

F.A. Mbuh, M. Galadima, and L. Ogbadu (2003). "Rate of co-infection with malaria parasites and Salmonella typhi in Zaria, Kaduna State, Nigeria," Annals of African Medicine vol. 2, no. 2 pp 64-67

Falola, Toyin; Amanda Warnock (2007). Encyclopedia of the Middle Passage: Greenwood Milestones in African American History. Greenwood Publishing Group P.92. ISBN 0-31333480-3

Global Malaria Action Plan, Malaria today (2013) Online. Available www.rbm. who.int/gmap. Accessed 25 April, 2015.

H.M Alhasan, N.N. Shidali, S.B. Manga, K. Abdullahi, and K.M. Hamid (2012). "Co-infection profile of Salmonella typhi and malaria parasite in Sokoto ,Nigeria." Global Journal of science, Engineering and Technology, vol. 2, no. 201, pp. 13-20.

H.M. Gilles (1993). "Immunology of Malaria", in Bruce-Chwatt's Essential Malariology, H.M Gilles and D. A Warrell. Eds., pp 85-103, Edward Arnold. London, UK.

Hackett, Rosalind I.J. (1989). Religion in Calabar: The Religious Life and History of a Nigerian Town. Watter de Gruyter.p.180. ISBN 3-11-011481

K.O. Akinyemi, B.S. Barmo, and A.O. Coker (2007). "Salmonellosis in Lagos, Nigeria. Incidence of Plasmodium 
falciparium - associated co-infection, pattern of antimicrobial resistance, and emergence of reduced susceptibility to fluoroquinolones,' Journal of Health, Population and Nutrition. Vol. 25, no. 3, pp.351-358

Lerner K.L; Lerner BW (2003). World of Microbiology and Immunology, vol. 1 and $2: 5,7,25,185-189$.

Linear Chemicals SL Joaquim Costa, 18-2 ${ }^{\mathrm{a}}$ Planta 08390 Montgat Barcelona, Spain

M.E. Ohanu, A.U. Mbah, P.O. Okonko, and F.S. Nwagb (2003). "Interference by malaria in the diagnosis of typhoid using Widal test alone," West African Journal of medicine. Vol. 22, no. 3

Malaria fact sheet No 94. WHO. March 2014. Retrieved 28 August, 2014.

Mbuh, F.A, Gialadima, M. and Ogbadu, L. (2003). Rate of co-infection with malaria parasites and Salmonella typhi in Zaria, Kaduna State: Annals of African Medicine 2:64-267

Meseret Birhanie, Belay Tessema, Getachew Ferede, Mengistu Endris and Bamlaku Enawgaw (2014). Malaria, Typhoid Fever, and their co-infection among Febrile Patients at a rural Health Centre in Northwest Ethopia: A cross-sectional study Advances in Medicine, Article ID 531074, $\quad 8 \quad$ Pages http;//dx.doi.org/10.1155/2015/531074

Michaella Siatta Kargbo, Lamin Daddy Massaquoi, Sallieu Kabay Samura, Xiaojing Meng, Fei Zou (2014). The relative prevalence of Typhoid and malaria in febrile patients in Freetown, Sierra Leone. Open Journal of preventiveh medicine, 4, 338-346. http://dx.

Doi. org/10.4236/ojpm.2014.45041

Monica Cheesbrough (2005). Examination of blood for parasites. District Laboratory Practise in Tropical Countries, second edition, part 1, Cambridge University Press, pp 244-
250

Monica Cheesbrough (2006). District Laboratory Practice in Tropical Countries (Part1), Cambridge University Press, Cambridge, UK, 2nd edition

Nnabuchi, C.V and Babalola, D.I, (2008). The incidence and management of typhoid fever in Nigeria. Journal of Obafemi Awolowo University Medical Student's Association 14(1) 75 - 78 .

Nsutebu, F.F, Ndumbe, P.M. and Koulla, S. (2001). The occurrence of typhoid fever in Cameroon; over diagnosis due to misuse of widal test. Nigeria Journal of Microbiology. 24(1): 2224-2230

Ohanu, M.E, Mbah, A.U, Okonkwo, P.O. and Nwagbo, F.S (2003). Interference by malaria in the diagnosis of typhoid using widal test alone. West African Journal of Medicine 22:250-252.

Okore Oghale Owoma, Ubiaru Prince. Chigozirim, Nwaogwugoru Uzoamaka Gloria (2015). Prevalence of malaria and typhoid fever Co-infection: knowledge, Attitude and management practices among Residents of ObudaAba, Abia State, Nigeria. American Journal of Public Health Research vol 3, No 4, pp 162-166. http://pubs.Sciepub.com/ajphr/3/A/6

Onuigbo, M.A. (1990). Diagnosis of typhoid fever in Nigeria: Misuse of widal test. The American Journal of tropical medicine Hygiene. 84(1): 129-131.

Onyido. A. E., Ifeadi, C.P., Umeanaeto. P. U., Irikannu, K. C., Aribodor, D. N., Ezeanya, L.C., Ugha, C. N., and Obiechina, I. O., (2014). Co-infection of malaria and Typhoid Fever in Ekwulumili Community, Anambra State. Southeastern Nigeria. New York Science Journal. 7(7) 18-27.

P. Pradhan (2011). "Co-infection of typhoid and malaria. Review" Journal of Medical Laboratory and Diagnosis. 
Vol. 2 no. 3, PP. 22-26.

Pang, T.Z., Bhutta, A., Finlay, B.B and Altweg, M, (1995). Typhoid fever and other Salmonellosis: a continuing challenge. Trends microbiology 3:253255.

Reither, P. (1999). "From Shake Spear to Defoe: Malaria in England in the little Ice Age". Emerging Infectious Disease 6(1): 1-11doi:10.3201/erd0601.000101Pmc 2627969 PMID 10653562

Rooth, I. and Bjorkman, A. (1992). Fever Episodes in a holoendemic malaria area of Tanzania: Parasitological and clinical findings and diagnostics aspects related to malaria. The American Journal of Tropical Medicine and Hygiene 86:476482.

Rupashree, S., Jamila, M., Sanjay. S. and Ukatu, V.E, (2014). Kowledge, Attitude and Practices on malaria among the rural communities in Aliero, Northern Nigeria. Journal of family Medicine and Primary care. 3(1)39-44.

S. k. Sharma, R. Chattopadhyay, K. Chakrabadi et al. (2004). "Epidemiology of malaria transmission and development of natural immunity in a malaria-endemic village San Dulakuda in drissa state, India". The Ameriac Journal of Tropical medicine and Hygiene. Vol 71, no. 4 pp. 457465.

Simon O. Ering (2010). "The population Situation in Cross River State of Nigeria and its implication for SocioEconomic Development: Observations from the 1991 and 2006 Censuses".

Strong Richard P (1944). Stitt's Diagnosis, prevention and Treatment of Tropical Diseases (seventh Ed.) York, PA: The Blakiston Company p.3

Ukpai, O.M and Ajoku, E. I (2001). The Prevalenec of Malaria in Okigwe and Owerri Areas of Imo State. The Nigeria Journal of Parasitology, 22(192): 4348.

V. A. Pam, S. Landan, D.D. Pam, J.F. Gulleek, J. Okoro, K.I. Ogbu, C.J. Bot, A. O. Akinyera (2015). "The Prevalence of malaria and typhoid coinfection in pregnant women attending antenatal in Wuse General Hospital Abuja, Nigeria". Scientific Journal of Veterinary Advances. Vol 4, No 6

Wain, J., Hendriksen, R.S., Mikoleti, M.L., Keddy K.H. and Ochiai, R.L (2015). Typhoid fever. Lancet 385(9973):11361145.

World Health Organisation , Typhoid vaccines (2008). WHO position paper. Weekly epidemiological record 83(6): 49-59.

World Health Organization, World malaria Report (2013). Online. Available http://kff.org/global-health-policy/factsheet/the-global-malaria-epidemic.

Accessed on 15 March, 2015

World Health Organization, World Malaria Report, (2011) http://www.who.int/ malaria/WMR2011.

\section{How to cite this article:}

Orok, Daniel Archibong, Usang, Akedor Ibor,Ikpan, Ogbe Oyama, Duke, Edisua E, Eyo, Emem Efeffiom, Edadi Ukam Ekup, Ati, Boniface Unimke and Udida, Job Akung. 2016. Prevalence of Malaria and Typhoid Fever Co-infection among Febrile Patients Attending College of Health Technology Medical Centre in Calabar, Cross River State, Nigeria. Int.J.Curr.Microbiol.App.Sci. 5(4): 825-835. doi: http://dx.doi.org/10.20546/ijcmas.2016.504.095 